\section{Past masters}

\section{Bernard Wood}

Getting Here: The Story of Human Evolution. By William Howells. Compass: 1993. Pp. 261. £26 (hbk); £14.50 (pbk). (UK distribution, Bailey.)

IN the library of my old medical school, books on evolution were next to the anatomy section. When I grew weary of the brachial plexus or failed once again to appreciate the nuances of cardiac development, I would often browse through them. Few new volumes were ever added, but one that did appear was Mankind in the Making by William Howells. I read it from cover to cover and it was probably one of the reasons I strayed from the path of medical righteousness and became a student and then teacher and researcher of human evolution.

Medical students are not renowned for the depth of their literary appreciation, and I was no exception. But even I could recognize a writing style that suggested that rare combination of a learned man who wore his learning lightly. The style was direct, authoritative and engaging, the antithesis of patronizing. It was not until much later that I realized that Howells's literary style was probably the product of both nature and nurture. Harvard contributed the nurture and a grandfather, a writer by the name of William Dean Howells, undoubtedly supplied the nature.

The human evolutionary history that Howells so infectiously recounted back in the early 1960 s was a relatively simple story based exclusively on fossil evidence. Nearly all forms of extinct hominids were located, at one place or another, in a sequence that led to modern humans. Molecular anthropology had yet to make an impact on the study of human evolution, and morphometry was only just being exploited as a tool to measure the similarity in form between fossils. In the event, no-one has subsequently used multivariate morphometrics to better effect than Howells. Over many years he has accumulated a unique dataset of measurements of modern human crania. These data include all the principal geographical variants of Homo sapiens and their interpretation has been the focus of Howells's research for the past two decades.

It is a reflection of the quality of this research that such a potentially contentious endeavour has been undertaken without controversy. In his most recent monograph, "Skull Shapes and the Map" (Papers of the Peabody Museum, No. 79, Harvard University, 1989), Howells added 10 cranial series to his original 18 and considered patterns of variation with- in and between the 28 samples. The research was designed to probe the link between genes and phenotype. To what extent are variations in modern human cranial form determined by 'deep' evolutionary history as opposed to relatively recent environmental selection pressures? Evolutionary trees, or dendrograms, based on cranial forms are then compared with those generated using the observed distribution of genetic markers, including mitochondrial DNA.

In studying the origin of modern humans, any attempt to analyse and interpret the fossil evidence should try to correct for the effects of differences in temperature and humidity on the phenotype of the modern human cranium. But few workers make this effort. It is no coincidence that nearly all those now assessing the evolutionary implications of modern human cranial variation do so using Howells's database, which is freely and generously made available to those who request it. Howells's recent study provided no support for the regional continuity hypothesis, which states that, post-Homo erectus, 'vertical' local continuity was a much stronger influence than 'horizontal' gene flow between contemporaneous populations. But nor did it provide compelling evidence to support a sub-Saharan origin for anatomically modern humans.

Now well into his $80 \mathrm{~s}$, Howells has once again written a survey of human evolution. The title Getting Here and the use of the word 'story' in the subtitle are, I suspect, a gentle dig at those who regard all attempts at presenting human prehistory as variations on a folklore narrative, in which the hero triumphs over adversity. The book is a narrative account of human evolution, but Howells makes it abundantly clear that human evolution was neither preordained nor inevitable. He uses all the benefits of a narrative to carry the reader through the confusing maze of fossil evidence. Howells has been successful in his attempt to explain to the general reader how palaeoanthropologists go about the task of reconstructing human evolution. The book concentrates on morphological evidence, and although it sets some of that evidence in its environmental context, neither ecology nor palaeoecology appears in the index.

Earlier accounts of human evolution, including those of Howells, stress the linearity of the human family tree; the tree appears more like a telegraph pole than a bush. In his latest account, Howells suggests that hominid evolution is best seen as series of 'bush-like' adaptive radiations. Within each radiation there is a potentially confusing mosiac of dietary, locomotor and other behavioural adaptations and abilities. Thus, for example, bipedalism and encephalization - the acquisition of a relatively large brain - may have evolved more than once. Howells's comprehensive treatment of the origin of anatomically modern humans is particularly good. It eschews the more confrontational style of much of the 'regional continuity' versus 'out of Africa' debate and, instead, takes the trouble to tell the reader how he or she might go about assessing the evidence.

If the potential for wealth creation is to become an all-powerful influence on science policy, then much of palaeontological science is doomed. But if public interest is to be the criterion, we are a long way from slaking the public's thirst for knowledge about our past. Howells's new book is a balanced and intellectually rigorous account of human evolution that is mercifully free from partisan adherence to a particular evolutionary picture. To an author well into his eighty-fifth year, the title has a special significance. We must be grateful that Howells's deep appreciation of human evolution has been updated and made available to a general audience. He tells us that this really is his final performance: if so, we shall miss the clarity of his analysis and the elegance of his writing.

Bernard Wood is in the Department of Human Anatomy and Cell Biology, University of Liverpool, PO Box 147, Liverpool L69 3BX, UK.

\section{Baby talk}

\section{PaulFletcher}

The Child's Path to Spoken Language. By John L. Locke. Harvard University Press: 1993. Pp. 518. \$39.95, £27.95.

JoHN Locke, the philosopher of mind, might have been surprised at the prelinguistic abilities of the young infant that are enumerated here by his twentiethcentury namesake. Neonates appear to be able to mimic an adult's facial gestures soon after birth - even before they have seen their own face. And two-month-old babies are sensitive to the difference between sounds such as $b$ and $g$, even though this contrast will not be used linguistically until at least a year later. The original Locke would also have been impressed by the detailed and careful sifting of empirical evidence in this account of the infant's first year or so of linguistic life.

Current accounts of the development of language, whether they are concerned with normal or abnormal development, tend to concentrate on the period after the first recognizable use of words: that is, on the child's transition from words to grammar and the subsequent development of grammatical capacity. The dominant view has been that language is a uniquely 